\title{
OMNIPRESENCE, INDWELLING, AND THE SECOND-PERSONAL
}

\section{ELEONORE STUMP}

\author{
St Louis University
}

\begin{abstract}
The claim that God is maximally present is characteristic of all three major monotheisms. In this paper, I explore this claim with regard to Christianity. First, God's omnipresence is a matter of God's relations to all space at all times at once, because omnipresence is an attribute of an eternal God. In addition, God is also present with and to a person. The assumption of a human nature ensures that God is never without the ability to be present with human persons in the way mind-reading enables; and, in the indwelling of the Holy Spirit, God is present in love.
\end{abstract}

\section{INTRODUCTION}

The claim that God is maximally present is characteristic of all three major monotheisms. ${ }^{1}$ In this paper, I want to explore this claim with regard to Christianity, which is the monotheism I know best. It is clear that there are various kinds of presence, for human beings as well as for God. For human beings, for example, being present can be a matter of being here now. Analogously, even for immaterial God, there is a kind of presence that involves relations to both space and time. The relations involved in presence with regard to space and time are typically characterized as presence in or presence at.

${ }^{1}$ God's omnipresence is the subject of an increasing literature in contemporary philosophy. For a representative excellent example, see Hud Hudson, 'Omnipresence', The Oxford Handbook of Philosophical Theology, Thomas P. Flint and Michael C. Rea, eds. (Oxford: Oxford University Press, 2009), pp. 199-216. My focus in this paper is on a side of omnipresence not often investigated in the standard treatments of it. 
In addition, however, there is also the kind of second-personal presence that one human person can have to another. This is the kind of presence we have in mind when we say, for example,

'She read the paper all through dinner and was never present to any of the rest of us'

or

'He sat with me at the defendant's table, but he was never really present with me during the trial.'

In these examples, there is presence at a time and in a place; but some kind of presence, characterized by one or another kind of second-personal psychological connection, is missing. Typically, this kind of presence is characterized as presence with or presence to another person. I will call this kind of presence 'personal presence'.

Personal presence itself comes in different kinds. In mindreading and empathy, for example, there is a kind of personal presence that has something of the character that telepathy would have if telepathy were real, as it is not. In empathy, for example, one can feel within oneself another person's pain, for example; in mind-reading more generally, one can somehow sense as internal to one's own psychology another person's intentions or emotions. When one person Paula mind-reads another person Jerome, Paula is in some sense there, present with Jerome.

This is a kind of unilateral personal presence, but mutual personal presence is also possible. It is mediated by a certain kind of mutual awareness, of the kind that arises, for example, when two people lock eyes. Mutual personal presence manifestly comes in degrees. There is the minimal kind that can arise when one catches the eye of a total stranger on a bus. At the other end of the scale, there is the kind of intense personal presence possible between those united through mutual love. In mindreading, one person somehow has within himself something of the mind of another. In mutual love between persons, there can be something stronger than such an asymmetrical relation; there can be a mutual inness' between the persons united in love, in a way that yields powerful personal presence. We might call this 'second-personal presence.'

${ }^{2}$ I have discussed the nature of the second-personal at length in my Wandering in Darkness: Narrative and the Problem of Suffering (Oxford: Oxford University Press, 2010), chapters 4 and 6 . For an excellent contemporary attempt to explain the nature of 
Since there is one mind and will in God, in our sense of 'person', God is a person too. ${ }^{3}$ And so it is in principle possible for God to have personal presence to or with human persons as well; and Christian theology emphasizes God's desire for union in love with human persons. In what follows, I will argue that, on Christian doctrine, even the personal presence generated by mind-reading and empathy are possible for God. In addition, something analogous to mutual 'in-ness' is possible for God with respect to those who love him. But, for God, this 'in-ness' has an ontological reality that is not available in the case of mutually loving human beings. For lack of a better term, I will use an old theological term and refer to this most intimate and powerful kind of second-personal presence between God and a human person as God's 'indwelling' a human person.

In this paper, I will say something briefly about God's presence with regard to time and space, and then I will focus on God's personal presence to and with human persons through mind-reading and through God's second-personal indwelling in those who love God.

\section{PRESENCE WITH REGARD TO TIME}

God's presence with respect to time is formulated in the doctrine of eternity. Contrary to the way it is sometimes thought of, eternity is not just timelessness. Rather it is a mode of existence characterized both by the absence of succession and also by limitless duration. Because an eternal God cannot have succession in his life, neither of the series (the so-called 'A series' or 'B series') characteristic of time can apply to God's life or to God's relations with other things. That is, nothing in God's life can be past or future with respect to anything else, either in God's life or in time; and, similarly, nothing in God's life can be earlier or later than anything else either.

On the other hand, because eternity is also limitless duration, God's life consists in the duration of a present that is not limited by either future

the second-personal in connection with child development, see Vasudevi Reddy, How Infants Know Minds (Cambridge, Mass.: Harvard University Press, 2008).

${ }^{3}$ For a discussion of the ways in which a simple God can be considered a person, see my 'Simplicity and Aquinas's Quantum Metaphysics', ed. Gerhard Krieger, 2014; see also a shortened and revised version, 'The Nature of a Simple God', American Catholic Philosophical Quarterly, forthcoming. 
or past. ${ }^{4}$ Since the mode of existence of an eternal God is characterized by this kind of presentness, the relation between an eternal God and anything in time has to be one of simultaneity. Of course, the simultaneity associated with an eternal God cannot be temporal simultaneity. Taking the concept of eternity seriously involves recognizing that it introduces technical senses for several familiar words and phrases, including 'now' and 'simultaneous with', as well as for the present-tense forms of many verbs. The relations between eternity and time therefore require a special sense of 'simultaneity'. In earlier work, Norman Kretzmann and I called this special sort of simultaneity 'ET-simultaneity', for 'simultaneity between what is eternal and what is temporal.'

The logic of the doctrine of eternity has the result that every moment of time, as that moment is now in time, is ET-simultaneous with the whole eternal life of God. Or, to put the same point the other way around, the whole of eternity is ET-simultaneous with each temporal event as that event is actually occurring in the temporal now.

It helps in this connection to consider the question: 'Does an eternal God know what time it is now?' For the sake of discussion, suppose that, for things in time, there is an absolute temporal now, as distinct from a now that is merely relative to some particular temporal entity. Could an eternal God know what time the absolute temporal now is?

On the supposition that in time there is an absolute now, then in time there is a fact of the matter about how far history has unrolled. With regard to the inhabitants in time, at any given moment in time as that moment becomes the absolute now, history has unrolled that far. And this is something an eternal God can know. Furthermore, because the whole of eternity is ET-simultaneous with each temporal event as it is actually occurring in the absolute temporal now, for every time an eternal God can know all the events actually occurring at that time as well as the temporal location of that time and its being experienced as the absolute now by temporal entities at that time.

${ }^{4}$ For detailed discussion of this doctrine, see Chapter 4 of my Aquinas (London and New York: Routledge, 2003) and my 'The Openness of God: Eternity and Free Will', ed. Ben Arbour, (forthcoming).

${ }^{5}$ A relationship that can be recognized as a kind of simultaneity will of course be symmetric. But, since its relata have relevantly distinct modes of existence, ETsimultaneity will be neither reflexive nor transitive. In particular, each of two temporal events can be ET-simultaneous with one and the same eternal event without being ETsimultaneous with each other. 
But after these things, there is nothing further for God to know about what time it is now. There is no time in the eternal now; and, in the eternal now, God is present to every temporal event, as it is part of the absolute temporal now. In the life of an eternal God, no temporal moment has any more claim than any other to be for God the absolute now.

One crude but helpful heuristic device for depicting the relation of eternity to time is to think of the time line as having an illuminated, yellow element indicating the absolute temporal now. Then for things in time, only one point on the line is ever yellow, although what point is yellow is always changing. For God in the eternal now, however, the entire time line is yellow.

An analogy may help here. If there were such a thing as Flatland, as described in Erwin Abbott's famous story of that name, then there would be more than one mode of spatial existence for sentient beings. There would be both the two-dimensional Flatland mode of spatial existence, for the story's sentient squares, and the three-dimensional mode of spatial existence, for more familiar sentient creatures. And if Flatland were linearly ordered with an absolute middle, there would be an absolute Flatland here, which in the Flatland world could be occupied by only one Flatlander at a time. Nonetheless, if Flatland were small enough, then, with respect to a human observer in the three-dimensional world, all of Flatland could be here at once (where the here of Flatland and the here of the three-dimensional world are only analogous to one another, not identical). And yet it would not follow and it would not be true that all of Flatland would be here with respect to any sentient occupant of Flatland. So it could be true both that only one sentient square in Flatland could be here at once (with respect to the here of Flatland) and also that all of Flatland could be here at once (with respect to the here of the threedimensional world). The reason for this apparently paradoxical claim is that all of Flatland can be encompassed within the metaphysically bigger here of the three-dimensional world.

An analogous point holds with regard to now, on the doctrine of eternity. With respect to God in the eternal now, all of time is encompassed within the eternal now, in the sense that all of time is ETsimultaneous with the eternal now. ${ }^{6}$ Just as the whole Flatland world can be here for someone in three-dimensional space, so all of time can be

${ }^{6}$ But it does not follow and is not true that all of time is present with respect to anything temporal at any particulartemporal location. 
now for God in the eternal now. Abbott's Flatland was written in order to illuminate the difficulties of thinking oneself up the ladder of being. In his story, a sentient square in Flatland makes contact with a sentient three-dimensional sphere and struggles to understand what life in the three dimensional world could possibly be. The doctrine of eternity has the implication that, with respect to time, sentient temporal beings are in the position of Flatland's sentient square as they try to understand a metaphysically greater God, whose now is eternal - limitless duration without succession - rather than the more limited and more familiar temporal now.

The result of God's eternity is that in respect of time God can be more present with regard to a human person Paula than any other contemporary human person Jerome can be. As regards Paula, her contemporary Jerome can be present only one time slice after another. When Paula is thirty years old, for example, neither her three-year old self nor her sixty-year old self are available to Jerome. But eternal God is present at once to every time of Paula's life; none of Paula's life is ever absent or unavailable for God.

\section{PRESENCE WITH REGARD TO SPACE}

As for space, mutatis mutandis, analogous things can be said, because God is not material, any more than God is temporal.

Aristotle says that a place contains a material body only if the outermost edge of what is contained and the outermost edge of the place coincide. ${ }^{7}$ If this is right, then since God is not a body and so has no outermost edges at all, God cannot be in a place, in the sense that the place contains him. (For similar reasons, nothing can be in God in this sense; in the Aristotelian sense of 'place', God cannot be a place for material things.) But although God cannot be present in a place as in a container, God can be present at a place.

Presence at a place is a complicated notion. In earlier work, ${ }^{8}$ Norman Kretzmann and I tried to capture this relation in terms of God's having direct and unmediated causal contact with and cognitive access to things

${ }^{7}$ Aristotle, Physics 211 b.

${ }^{8}$ Eleonore Stump and Norman Kretzmann, 'Eternity, Awareness, and Action', Faith and Philosophy, 9 (1992), 463-82. 
at a place. $^{9}$ I now think, however, that the attempt to capture presence at a place in terms of direct and unmediated cognitive and causal connection misses something.

Consider, for example, Homer's depiction of Zeus. Wherever in physical reality he is, Homer's Zeus has direct and unmediated causal contact with the Trojans at the place of the Trojan war and also direct and unmediated cognitive access to them. That is, Zeus knows directly and immediately what is happening to the Trojans in the fighting with the Greeks, say, and he can affect the way the fighting goes just by willing it. But Zeus can continue to have such cognitive and causal contact with the Trojans at the place of the Trojan war even when he is (as Homer sometimes says) having dinner with the Ethiopians. While Zeus is among the Ethiopians, however, he is absent from the place of the Trojan War, not present at it.

Elsewhere I have argued that what is missing for Zeus in this Homeric story can be explained in terms of shared or joint attention. ${ }^{10}$ It is hard to give a good philosophical analysis of joint attention, but easy to give examples of it. An infant engages in joint attention when the infant looks into the eyes of the mother, who is looking back into the infant's eyes. In adults, joint attention is at least partly a matter of mutual awareness, of the sort that prompts philosophical worry about the possibility of an unstoppable infinite regress: Paula is aware of Jerome's being aware of Paula's being of Jerome's being aware, and so on. ${ }^{11}$ In shared attention, the object of awareness for Paula is simultaneously Jerome and Jerome's awareness of her awareness of his awareness and so on - and the object of awareness for Jerome is simultaneously Paula and their mutual awareness.

${ }^{9}$ By 'direct and unmediated' in this context, I mean only that the cognitive access or the causal connection does not have as an intermediate step the agency of another person; I do not mean that there is no intermediary of any sort.

10 See, 'Eternity, Awareness, and Action' (with Norman Kretzmann), Faith and Philosophy, 9 (1992), 463-482.

${ }^{11}$ Because philosophers take knowledge to be a matter of knowledge that, a more common philosophical formulation of mutual knowledge would be in terms of knowing that: Paula knows that Jerome knows that Paula knows that Jerome knows, and so on. In the case of infants, of course, shared attention cannot be a matter of knowing that in this way. For an interesting study of mutual knowledge in connection with joint attention, see Christopher Peacocke, 'Joint Attention: Its Nature, Reflexivity, and Relation to Common Knowledge', in Naomi Eilan, Christoph Hoerl, Teresa McCormack, and Johannes Roessler, eds., Joint Attention: Communication and Other Minds (Oxford: Oxford University Press, 2005), pp. 298-324. 
These attempts at philosophical characterization of joint attention are inadequate, and I offer them only to help prompt intuition about the nature of joint attention. Roughly put, one can say that joint attention is a kind of second-person experience between two persons who are mutually aware of each other. ${ }^{12}$ Joint attention is most often mediated by vision; but it can be mediated by other senses as well. A congenitally blind child can share attention with its mother by sound or by touch, for example. In the case of an immaterial God, joint attention can occur without any mediation by the senses, provided that there is iterated mutual awareness. The senses are typically the vehicle for establishing joint attention, but they are not essential to it.

Between human persons, presence at a place includes not joint attention, but the mere availability for joint attention; and something similar can be said about Homer's human-like Greek gods. In the case of Zeus in the story, Zeus is not present at the place of the Trojan war when he is having dinner with the Ethiopians, because, even though he has direct and unmediated cognitive and causal contact with that place and the things in it, he is not available to share attention with the Trojans at that place. Zeus's power extends to the place of the Trojan war; but, one might say, his face does not. A Trojan might address a prayer to Zeus while Zeus is among the Ethiopians, in the assurance that Zeus would hear it and could immediately answer it by altering the course of the war. But it is possible for Greek gods to engage in face-to-face interaction; and Zeus is not available for that kind of interaction with anyone at the place of the Trojan war while he is away among the Ethiopians. For this reason, Zeus is not then present at the place of the Trojan war either.

So one ingredient in a person's presence at a place is that person's availability for sharing attention with other persons also present at that place. Mutatis mutandis, this point about the connection between shared attention and presence at a place applies also to God. God's having direct and unmediated cognitive and causal contact with everything at any place is still insufficient for God's being present at every place. In order for God to be present at every place, as Christianity claims God is, it also needs to be the case that, for any person at any place who is able and willing to share attention with God, God is available to share attention with that person.

${ }^{12}$ For more discussion of the second-personal and of joint attention, see Chapters 4 and 6 of my Wandering in Darkness (Oxford: Oxford University Press, 2010). 
On Christian doctrine, then, the relation of an omnipresent God to a human person located in space is analogous to the relation between the sentient three-dimensional sphere and the sentient two-dimensional square in Abbott's Flatland. The space that is here for the square is much more limited than the space that is here with regard to the sphere, which is metaphysically greater than the square. Analogously, although only a limited region of space is here with regard to a human person in a place, for God the entirety of space is here, even in the sense that God is available at once to share attention with any human person at any location in space.

In this respect, there is parity between God's relation to space and God's relation to time. In one and the same eternal present, omnipresent God is available to share attention with any person at any place in any time. Because of the way God is present at a place and in a time, for all persons, in whatever place and time they are, God is at once present, in power and knowledge and also in person.

\section{PRESENCE BETWEEN HUMAN PERSONS: EMPATHY, MIND-READING, AND UNION IN LOVE}

In addition to these kinds of presence at a place or in a time, as between human persons yet another kind of presence is possible.

This kind of presence can be understood in relation to mind-reading and empathy. We now know much more about empathy than we did only a few decades ago, and we understand that one kind of cognition afforded by the recently discovered neurological capacities that subserve empathy includes mind-reading more generally.

In human beings, mind-reading is the knowledge of persons and their mental states. ${ }^{13}$ Because of recent work in neuroscience and developmental psychology, especially work on the impairments of development among autistic children, we have learned a great deal about the neurological systems that make empathy and mind-reading possible and the kind of cognition these systems produce. Whatever ties together the different clinical signs of all the degrees of autism spectrum disorder,

${ }^{13}$ Mind-reading or some analogue of it can be found in species other than human beings and also between members of different species, including between human beings and other animals; and so the qualification 'in human beings' is necessary here. 
the most salient feature of the disorder is an impairment in the cognitive capacities necessary for mindreading. ${ }^{14}$

The knowledge which is impaired for an autistic child, however, cannot be taken as knowledge that something or other is the case. A non-autistic pre-linguistic infant is capable of mind-reading; she can know her mother, and to one extent or another she can also know some of her mother's mental states. But she is not capable of knowledge that a particular person is her mother. Conversely, an autistic child can know that his mother is sad - say, because she has told him so and she is a reliable authority on such matters for the child. But the impairment

${ }^{14}$ Among philosophers, there is not one universally accepted understanding of the notion of mind-reading. It seems to me to be taken ambiguously, in a way analogous to the ambiguity in the notion of perception. The notion of perception can be taken as (i) perception, (ii) perception as, and (iii) perceptual belief. To say that Max has a perception of a cup can be understood to mean:

(i) the cup is an object of perception for Max,

(ii) Max perceives the cup as a cup,

(iii) Max perceives that that is a cup.

The notion of mind-reading seems to me ambiguous in the same way. The reason for the ambiguity is that, in ordinary cases in which a cognitive capacity is operating normally, it operates as part of a whole system to give information available to consciousness, connected with other information stored in the system, and formulable in beliefs. For reasons I have given elsewhere, it seems to me better to take perception in sense (ii) than in sense (i) or sense (iii). (See Stump 2003, Chapter 8, especially the section on perception.) In this paper, I will understand mind-reading analogously, in sense (ii), rather than sense (i) or sense (iii).

In this respect, I dissent from Alvin Goldman's use of the term 'mind-reading'. His use of the term is a variant on (iii). He says: 'By "mindreading" I mean the attribution of a mental state to self or other. In other words, to mind-read is to form a judgment, belief, or representation that a designate person occupies or undergoes (in the past, present, or future) a specified mental state or experience.' (Alvin Goldman, 'Mirroring, Mindreading, and Simulation', in Jamie Pineda (ed.), Mirror Neuron Systems: The Role of Mirroring Processes in Social Cognition (New York: Springer, 2009), p. 312) On Goldman's usage, it would not be true to say that autistic children are impaired with respect to mindreading, since it is possible for them to form judgments about the mental states of others.

But in order to explain what is impaired in autism, we need a term like 'mind-reading' in sense (ii). Since 'mind-reading' is the term already employed for this purpose by many philosophers and researchers on autism, it seems to me better to continue to use the term in that way rather than in Goldman's way. Goldman's goal is to interpret mindreading in such a way as to make the new results in neurobiology compatible with his own attempts to understand mind-reading in terms of simulation theory. For arguments against Goldman's position on this score, see Shaun Gallagher's article in the same volume, 'Neural Simulation and Social Cognition', pp. 355-71. 
characteristic of autism can leave the child without the knowledge of the sadness of his mother. What is impaired for the autistic child is a nonpropositional knowledge of persons and their mental states.

Recent research in neuroscience has shown that the capacity for this kind of knowledge of persons is subserved at least in part by what is now called 'the mirror neuron system. The mirror neuron system makes it possible for one person to have knowledge of the mental states of another person when that knowledge shares something of the phenomenology of perception. Like the perception of colour, for example, the knowledge of persons in mind-reading is direct, intuitive, and hard to translate without remainder into knowledge that (but very useful as a basis for knowledge that of one sort or another).

Neurons in the mirror neuron system contribute to making the knowledge of mind-reading possible because they fire both when one does some action oneself or has some emotion oneself and also when one sees that same action or emotion in someone else. The point is easier to appreciate if we focus on empathy with another person's pain, which is currently also thought to be a result of the cognitive capacities subserved by the mirror neuron system. ${ }^{15}$ When Paula sees Jerome cut himself with a knife, she feels his pain, because Paula's mirror neuron system produces in Paula an affective state that has at least some of the characteristics of the pain Jerome is experiencing. Paula does not actually suffer physical pain resulting from a laceration in her tissues; but, in her empathy with Jerome, she has some kind of feeling of pain. Only, in Paula, that feeling is taken off-line, as it were, because in her it is not connected to tissue

15 There is a considerable literature on empathy. For a good introduction to some of the issues involved, see Alvin Goldman, 'Two Routes to Empathy: Insights from Cognitive Neuroscience', in Empathy. Philosophical and Psychological Perspectives, ed. Amy Coplan and Peter Goldie (Oxford: Oxford University Press, 2011), pp. 31-44. It is clear that there are at least two different kinds of empathy or levels of empathy. One is more nearly involuntary and also more coarse-grained. The other is under more voluntary control, more fine-grained, and more dependent on past experience and training. The first is in play when a person winces as he sees someone else get hurt. The second is engaged when someone is deeply involved in reading a novel. It seems clear that there is no sharp demarcation between these kinds, but rather a kind of continuum. The first kind of empathy, and any kind of empathy closer to that end of the continuum, is what is at issue in this paper. But, in my view, it would be possible to preserve the general point of this paper even if it turned out that the cognitive processes at issue required empathy of the second kind. 
damage, as it is in Jerome. ${ }^{16}$ Furthermore, even though in empathy Paula feels pain that is her pain, in the sense that the pain is in her and she herself feels it, she nonetheless recognizes this pain as Jerome's pain, not hers. The final result of the neural interactions begun by the mirror neuron system is that Paula knows that Jerome is in pain; but she knows this because, in consequence of the mirror neuron system, she first knows Jerome's pain. ${ }^{17}$

In general, in mind-reading Jerome, to one extent or another Paula will know the action Jerome is doing, the intention which Jerome has in doing it, and the emotion Jerome has while doing it. And Paula will know these things in Jerome through having herself some simulacrum of the mental state in Jerome. Something of Jerome's mental state will be in Paula, but in a different way.

One researcher on mind-reading, Vittorio Gallese, tries to explain the relevant neural mechanisms involved in the knowledge of persons this way:

[mirror neurons] map ... multimodal representation across different spaces inhabited by different actors. These spaces are blended within a unified common intersubjective space, which paradoxically does not segregate any subject. This space is 'we'centric ... The shared intentional space underpinned by the mirror matching mechanism is not meant to distinguish the agent from the observer. ${ }^{18}$

And he goes on to explain empathy in this way:

${ }^{16}$ It is not easy to say precisely what it is for a system to run off-line, but the general idea is this. In the case of dreamed motion, the brain's motor programs for actual physical running are off-line in that while these motor programs are firing, they are disconnected from the muscles in the legs and so do not produce running in the legs. In the case of mind-reading, the brain's mirror neuron system runs the programs it would run if one person were apprehending what the other, observed person is doing; but it runs these programs disconnected from those states of will and intellect the observer would have if she herself were doing those acts. In this way, she shares in the observed person's mental states but without having them as he has them, in virtue of having her own states of intellect and will, not his, even while she feels what she would feel if she were doing what he is doing.

${ }^{17}$ And, of course, on this basis she also knows that Jerome is in pain. Empathic feeling of his pain is a reliable ground for knowledge that he is in pain.

18 Vittorio Gallese, "Being Like Me": Self-Other Identity, Mirror Neurons, and Empathy', in Perspectives on Imitation: From Neuroscience to Social Science, ed. Susan Hurley and Nick Chater (Cambridge, Mass.: MIT Press, 2005), p. 111. 
Self-other identity goes beyond the domain of action. It incorporates sensations, affect, and emotions. ... The shared intersubjective space in which we live from birth continues long afterward to constitute a substantial part of our semantic space. When we observe other individuals acting, facing their full range of expressive power (the way they act, the emotions and feelings they display), a meaningful embodied link among individuals is automatically established. ... [S]ensation and emotions displayed by others can also be empathized with, and therefore implicitly understood, through a mirror matching mechanism. ${ }^{19}$

In human mind-reading, there is a sense in which something of the thought, affect, or intention in the mind of one person is in the mind of another. In the intermingling of minds made possible by the mirror neuron system, one person is present to another in virtue of being in that other, in a way that the neurobiology of the brain makes possible. This is intersubjectivity, or presence with. In mind-reading, one human person can be present with another in a way more powerful than mere presence at a place or in a time.

The kind of presence to a person manifested in joint attention is broadened by the mind-reading cognitive system. When Paula mindreads Jerome, the relevant neural systems give Paula a direct, quasiperceptual awareness of Jerome's actions, emotions, and intentions. And this awareness arises in Paula because in mind-reading Jerome she is sharing something of Jerome's mental states. In this sharing and awareness, she is also present with Jerome, with personal presence.

There is a minimal degree of personal presence when Paula winces as she sees Jerome slice his finger with his steak knife, even if Jerome is unaware that Paula is observing him. This is a kind of presence of one person with another that is possible even if the two people involved are strangers to each other or know and heartily dislike each other. For example, Paula can wince at Jerome's pain even while she thinks that his suffering that pain serves him right.

But there is a much greater degree of personal presence when two people, who are mutually close to each other in a loving relationship, are mutually mind-reading each other in intense shared attention. When this kind of second-personal presence occurs, one way to describe the connection between the two people in question is to say that they are united in love.

${ }^{19}$ Gallese, 'Being Like Me', p. 111 and p. 114. 
This kind of experience is a staple of romantic literature and poetry. In his famous poem 'The Extasie', John Donne describes such an experience between lovers:

Our eye-beames twisted, and did thred

Our eyes, upon one double string

...

Our soules, (which to advance their state

Were gone out) hung twixt her, and me.

But this kind of being united is also possible between human beings in non-romantic or non-erotic relationship as well, as, for example, between a mother and her child or between a sick person and her loving care-taker.

In what follows, I will argue that both the mind-reading kind of presence with a person and the presence between persons united in love is possible for God and human persons.

\section{GOD'S PRESENCE WITH HUMAN PERSONS: EMPATHY AND MIND-READING}

Since, on orthodox Christian doctrine, God is omniscient, God knows all truths; and so God has propositional knowledge (or the divine equivalent of propositional knowledge $)^{20}$ as regards all the mental states of all human beings. God knows that Paula is sad or that Jerome is disgusted. But it seems that with respect to human persons, God cannot have empathy or the mind-reading kind of knowledge. And so it seems that one kind of intimate presence between persons, prized by human beings, is not possible for God to have with respect to human persons.

When Paula has empathy with Jerome, she feels within herself what Jerome feels. But in virtue of having no body, God has no feelings either. This is the point of the scholastic doctrine that God is impassible. Strictly speaking, a passio, which is the thing an impassible God does not have, is a feeling; and a feeling at least includes bodily sensations. Nothing immaterial can have bodily sensations, and so immaterial God has no feelings either, in this sense of 'feeling'. (This claim is very different from

20 The doctrine of simplicity complicates any attribution to God, so that God's knowledge of truths may need to be explained in a way only analogical to human propositional knowledge. 
the claim with which it is often confused, namely, the theologically unacceptable claim that God has no emotions.)

Mind-reading extends to more than knowledge of the feelings of another person, but all mind-reading is like empathy in having a shared character and a qualitative feel. When Paula mind-reads Jerome, she shares something of Jerome's mental state in virtue of somehow feeling that mental state in herself. A mental state that is Jerome's is somehow also Paula's and felt by Paula, except that Paula experiences it as Jerome's, rather than as her own. Paula knows Jerome's intention to hit her, say, because her mirror neuron system forms the neural pattern it would form if Paula were going to move her arm to hit someone; and so, by feeling it within herself, she knows Jerome's intention to hit. An immaterial God cannot form an intention to move his arm to hit, however, because he has no arm to move. And so although God can know that Jerome intends to hit Paula, it seems that he cannot mind-read Jerome's intention in the direct and intuitive way Paula can.

And the point generalizes. A human psyche is too small and God's mind is too great, one might say, for God to contain human mental states within himself in the shared way the mirror neuron system enables as between human beings. And so, it seems, the sharing and the presence that is the hallmark of the knowledge of persons is ruled out for God.

But appearances are misleading here. In this respect, Christianity has special resources because of the doctrine that God became incarnate in Christ. The Chalcedonian formula for the incarnate Christ stipulates that Christ is one person with two natures. The one person is the second person of the Trinity and is thus God, and the two natures are the divine and the human. It is one of the consequences of the Chalcedonian formula that there are in Christ two minds, one human and one divine, but only one person - a divine person - who is the possessor of these two minds. ${ }^{21}$ The far-ranging and significant implications of the Chalcedonian formula can be seen by thinking about suffering and death. When Christ suffers and dies, he does so in the human nature of Jesus; but the person suffering and dying is God. So, while it is theologically correct to say that God

${ }^{21}$ Some people might suppose that this description of Christ is incoherent and that philosophical reason can demonstrate that there could be nothing meeting this description. In Stump 2003, Chapter 14, I have examined the doctrine of the incarnation and attempted to defend it against at least some of the major arguments meant to show its incoherence. 
cannot suffer or die in his divine nature, it is not theologically correct to say that God cannot suffer or die. On the Chalcedonian formula, and validated by later theology, it is theologically correct to say that God suffers and that God dies. God can do both, in the human nature he assumed.

Furthermore, on the doctrine of eternity, God's having an assumed human nature is not something true of God at some times but not at others. It is something characteristic of God always in the limitless eternal now. So, on the doctrine of eternity, God is never in the state of not having an assumed human nature. ${ }^{22}$ For this reason, the human capacity for suffering is something that is never not characteristic of God, in the human nature whose assumption is never absent from God.

For these reasons, God can have empathy with human persons and can also mind-read them, since he can use the human mind of the assumed human nature to know human persons in the knowledge of persons way. He can therefore also be present with human persons in this way.

Furthermore, although it is part of orthodox doctrine that in Christ the two natures do not mingle, nonetheless, in virtue of the fact that only one person has these natures, and that one person is divine, Christ can act in such a way as to use elements of both natures in his actions. Even while acting in his human nature, Christ can use powers that are beyond the merely human and that are available to him only through his divine nature. For example, acting in his capacity as a human being, Christ does miracles; but he is able to do them because in his human actions he can harness the divine power over nature.

In the same sort of way, in his human nature, Christ can mind-read in ways not possible for mere human persons. When he does, it is the human nature doing the mind-reading; but the person doing the mindreading is divine and has access to divine power. So Christ has the ability to mind-read human beings deeply, or even miraculously, in a way that human persons otherwise could not do. ${ }^{23}$

In fact, since God is present to every time and space, Christ can use his human mind and the power of his divine nature to mind-read at

${ }^{22}$ To say this is, of course, not the same as saying that God's becoming incarnate is necessary to him. For Aquinas, for example, God's eternity and immutability are compatible with God's ability to do otherwise than God does.

${ }^{23}$ For one example, see the episode of the woman at the well (John 4:5-29). 
once the entire minds of all human beings at every time and space. To do so, Christ has to be willing to open himself up simultaneously to every human psyche. When he does so, then at that time all the mental states of all human beings will flood his mind, through the extended powers provided by his divine nature. In that opening to all human psyches, every evil emotion and intention ever had by any human being will then be in the human mind of Christ, too, through the divinely empowered extended human capacity for mind-reading.

The idea that Christ opens himself at once to this kind of spectacular and no doubt harrowing mind-reading is one way of understanding the traditional, scripturally based claim that on the cross Christ bore the sins of all humankind. On this way of interpreting that scriptural claim, the power of God gives the human mind of Christ the more than human power of feeling within himself at one and the same time the minds of all human persons, with all their sins. ${ }^{24}$

So, the Chalcedonian formula for the incarnate Christ gives a way of explaining and defending God's knowledge of persons through mind-reading and the presence with persons mind-reading enables. Through the human mind of Christ, God can mind-read other human beings. And if the mind-reading of Christ can occur in miraculous ways, employing the power of God to extend greatly the ordinary human capacity for mind-reading, then God can have at once the unilateral personal presence brought about in empathy and mind-reading with respect to all human persons.

\section{SECOND-PERSONAL PRESENCE: UNION IN LOVE AND INDWELLING}

The kind of presence God can have with all human persons in consequence of the incarnation falls short of the second-personal presence obtaining between persons united in love, however. When Christ mind-reads miraculously, he does so because of the power of his divinely enhanced human capacity for mind-reading. But this kind of mind-reading is unilateral, not mutual. And so there is an asymmetry that limits personal presence.

${ }^{24}$ I have described in detail what such an experience would be, and I have argued that it could give rise to the cry of dereliction from the cross in 'Atonement and the Cry of Dereliction from the Cross', European Journal for Philosophy of Religion, 4.1 (Spring 2012), 1-17. 
It is part of Christian doctrine, however, that when a person Paula comes to faith, she opens herself up to God in love. In an act of free will that is part of faith, Paula accepts God's grace and begins a relation of mutual love with God. In entering into this relationship, Paula accepts not only God's grace but also God himself.

When Paula comes to faith in this way, the Holy Spirit comes to dwell in her. However exactly it is to be understood, on the theological claims involving the Holy Spirit, the indwelling of the Holy Spirit puts the mind of God within Paula's psyche, in some sense. Because of this strong bond, the mutual relationship of love yields maximal second-personal presence of God to Paula.

The indwelling Holy Spirit is a common topic of Christian theology, ${ }^{25}$ but it is actually not easy to specify what this indwelling comes to. We can start by saying what it is not. God's indwelling in Paula is not merely a matter of God's having direct and immediate causal and cognitive access to Paula's mind. God has this kind of access to the mind of every human being, both with regard to propositional knowledge and also with regard to mind-reading. For every person, it is possible for God to know the mind of that person with direct and unmediated cognition; it is also possible for God to communicate in a direct and unmediated way with the mind of that person. And if the interpretation given above of Christ's mind-reading is accepted, then God also has the knowledge of persons with regard to all human beings, too. So these kinds of relation between God and human beings hold for every human person. The indwelling of the Holy Spirit, however, is found only in those people who have faith and love of God.

God's indwelling unites God and a human person in love, and so we might try understanding indwelling as an analogue to the psychic relation between human persons who are united in love. The psychic relation between mutually loving human beings is a particularly intimate kind of mind-reading accompanied by shared attention between persons when those persons are mutually close to each other. ${ }^{26}$ But this approach to explaining the indwelling of the Holy Spirit is not quite right either. The indwelling of the Holy Spirit is meant to be something ontologically more powerful than mutual closeness accompanied by shared attention.

${ }^{25}$ For a helpful discussion seeking to explain the effects of the indwelling Holy Spirit, see Aquinas's SCG IV. 21-22.

${ }^{26}$ For discussion and defence of this claim, see Stump 2010, Chapter 6. 
In the Holy Spirit's indwelling, God himself is somehow within each person of faith. Although, as I explained above, immaterial God cannot be contained within a material container, God's omnipresence does include his being somehow within the psyches of those who have faith.

In this connection, it helps to return to Gallese's attempt to describe the kind of cognition that mind-reading is. When Paula mind-reads Jerome's intention to hit her, for example, her mind goes into the configuration it would have if she were Jerome and preparing to hit. But this configuration is in Paula off-line, that is, not actually connected in an active way to her muscles. She has the motor configuration for hitting, but on her part no hitting occurs. So, the configuration of Jerome's intention is in Paula; and because it is, it is Paula's; but it is in Paula as Jerome's intention, and not as hers. This complicated state is what Gallese is trying to describe when he says that there is a 'we-centric' part of the human brain that enables a real sharing of mental states.

Gallese is talking about brain systems in order to make a point about mental states. Aquinas makes a very roughly analogous point about the mechanisms of cognition. For Aquinas, when a person Paula sees an object, such as a coffee cup, the configuration or form inhering in the cup which makes the matter of the cup be a cup is transferred to Paula's mind. The form that is in the cup is then also in Paula's mind, only in an encoded state. Or, as we might say, the configuration of the cup is transferred through a certain pattern of firing by Paula's retinal cells to Paula's visual cortex. In theory, it would be possible for a competent neuroscientist, who understands the neural coding involved, to look at the configuration in Paula's visual cortex and infer correctly that what is impacting her visual cortex is a cup. So, in some sense, the configuration of the cup is in both the cup and Paula, only in differing ways. Analogously, when Paula mind-reads Jerome's intention, there is a form or configuration in Jerome's brain that is found also in Paula's. She mind-reads him because she shares this form or configuration with him. The same configuration is in each of them, only differently insofar as it is off-line in Paula. ${ }^{27}$

Furthermore, although the configuration of the cup is really in Paula's mind when she sees the cup, that configuration is processed in Paula in such a way that, without ceasing to be the form of the cup, the

${ }^{27}$ I am grateful to John Foley, who suggested to me this way of explaining the point and its usefulness for understanding the nature of God's indwelling in a person of faith. 
configuration of the cup is encoded in Paula in such a way as to enable Paula to have cognition of the cup. Analogously, when the configuration of Jerome's intention is in Paula's mind, that configuration is in her mind in such a way as to enable Paula to have cognition of Jerome's intention, not hers. So, the configuration of Jerome's mind is in Jerome's mind and in Paula's at once, but Jerome feels it as his and Paula feels it as belonging to Jerome. It is possible, then, for a person Paula to have within herself, biologically and psychologically, something that is her own and yet also part of another person Jerome.

Furthermore, it is also possible for Paula to feel this dichotomy in a way that is subjectively accessible to her. Paula can consciously identify a mental state as within her own mind and yet somehow not hers but Jerome's. It is easiest to see this point in connection with empathy. If Paula sees Jerome impale his bare foot on a nail in the garden, she will wince with pain. So, something of Jerome's pain is in Paula; she winces because she feels it within herself. But even while she feels this pain in herself, she also is conscious that what she feels with pain is Jerome's pain and not her own. She is sharing with Jerome what is Jerome's.

Neurological research suggests that the brain has multiple systems for identifying parts of oneself as one's own - body parts, thoughts, and the self in general. ${ }^{28}$ If there are brain systems enabling social cognition and intersubjectivity, by means of 'we-centric' space that enable shared mental states, there are also brain systems enabling the distinction between self and other. When something goes wrong with these latter brain systems, dysfunctional mental conditions can result. For example, in consequence of an injury, a patient can suffer the delusion that some part of his body is not his own. ${ }^{29}$ In the view of some researchers, the psychological delusion of thought intrusion is yet another result of the malfunctioning of these brain systems. ${ }^{30}$

${ }^{28}$ As recent work in metaphysics highlights, there are also criteria for determining that a person's mind is his own, that it belongs to him, in ways hard to specify with precision, but crucial for issues of moral responsibility and freedom of will. For a discussion of some of the issues, see, for example, my 'Persons: Identification and Freedom', Philosophical Topics, 24 (1996), 183-214.

${ }^{29}$ For a vivid and popular description of such a case, see Oliver Sacks, A Leg to Stand On (New York: Harper and Row, 1984).

${ }^{30}$ In Fregoli's syndrome, a patient has the intractable delusion that he knows familiar people when he looks at the faces of strangers. In Capgras syndrome, a patient has the intractable delusion that he does not know the people he is looking at when he looks at the faces of persons who are in fact familiar to him. For discussion of such syndromes, 
Because of the systems of the human brain for recognizing some mental states as one's own, it is also possible for a person Jerome to have a sense of the mind operative in him as not his own but someone else's. ${ }^{31}$ In a case of this sort, the intersubjectivity of mental states enabled by the mirror neuron system and evident in mind-reading transforms from a mere psychological sharing to something that is ontological. What is in Jerome's mind is not just another person's thought or affect, but in fact that other person's mind. 'Indwelling' is not a bad word for this kind of relationship between minds. It does seem appropriate to say that in such a case the other person's mind indwells Jerome's mind.

Science fiction is replete with stories in which malevolent non-human beings indwell a human mind; ${ }^{32}$ and folklore has sometimes tended to explain certain kinds of mental illness along the same lines. ${ }^{33}$ Stories about such cases are frightening and revulsive because the indwelling mind invades the mind of the human person, against his will or at least without his consent. Typically, in such cases, the invader has only hatred and contempt for its human victim.

see, for example, Sandra Blakeslee and Vilayandur Ramachandran, Phantoms in the Brain (London: Harper Perennial, 2005), chapter 8. Both Fregoli's syndrome and Capgras syndrome are a kind of loss, after neurological damage, of the capacity to know something as the thing it is. Although these syndromes have been described largely as they affect the knowledge of persons, there are also reported cases in which the lost capacity extends to the knowledge of familiar things other than persons. So, for example, some researchers describe 'a patient who claimed his actual home was not his "real" home, although he recognized that the facsimile home has the same ornaments and bedside items as the original' (Todd Feinberg, John Deluca, Joseph T. Giacino, David M. Roane, and Mark Solms, 'Right-Hemisphere Pathology and the Self: Delusional Misidentification and Reduplication', in Todd Feinberg and Julian Paul Keenan (eds.), The Lost Self: Pathologies of the Brain and Identity (Oxford: Oxford University Press, 2005), p. 103; see also pp. 105106 and pp. 114-125).

${ }^{31}$ Because this is so, it is a common conceit of science fiction that the mind of one sentient creature can be within the mind of another one. The two minds can interact within the mind of one person, without either mind losing its identity. In the science fiction literature depicting a human being in such a condition, the indwelling mind is typically that of an alien. The alien is generally portrayed as smarter and more powerful than the human being his mind indwells. But in addition the alien mind is depicted as invading the human mind, entering it without the consent of the human being in question; and the alien's purpose is typically either indifferent to the welfare of the human being or actively malevolent towards him.

${ }^{32}$ Robert Heinlein's The Puppetmasters is an example.

${ }^{33}$ If one googles 'schizophrenia and demon possession', one will find that this sort of belief is still prevalent in some communities today. 
On the other hand, when two people Paula and Jerome are psychically united to one another in love, the interweaving of their psyches occurs only with the willingness of each to each. Paula's psyche is open to Jerome's because Paula wants it to be, and the same is true of Jerome's psyche with respect to Paula. The resulting mutual openness is wanted by each of them; and when they have it, it yields gladness and peace. Furthermore, insofar as they love each other, each of them wishes for the good of the other. And so the vulnerability of the openness of love is acceptable to each of them, because of the trust each is rightly willing to place in the other. ${ }^{34}$ Stories of two people united to each other in mutual love in this way are a staple of romantic stories, though, of course, mutual love of this compelling human kind is found across a broad range of human relationships. Depictions of human persons united in love in a variety of relationships is a perennial theme in great literature, and hardly anyone is completely immune to its attractions.

In the fullest expression of such uniting in love between Paula and Jerome, each of them is as second-personally present to the other as is possible between two human beings. But an even more powerful secondpersonal presence to a person is possible for God in the indwelling of the Holy Spirit.

The indwelling of the Holy Spirit requires welcome on the part of the human person in the relationship. When a person comes to faith and accepts God's grace in love, then and only then the Holy Spirit comes to indwell in the human mind of that person. The Holy Spirit is freely accepted by that person, and the union between them is characterized by mutual love, freely given and freely accepted.

In this union, what is within the psyche of a human person Jerome is not just the thoughts and intentions of God, but God himself. Nonetheless, nothing of Jerome's own individual personhood is lost in the process. Jerome's mind remains his own, and his awareness of his mind as his own also remains. Nonetheless, when the Holy Spirit indwells in his mind, Jerome will be aware of the Spirit's mind within his own.

${ }^{34}$ It might need to be said that it is possible for two people to love each other but not to be united in that love. They might instead love each other in ways that are conflicted or mutually self-destructive. But in those cases they are not united to each other, not least because each of them, in being conflicted, is divided against himself. For a discussion of such cases, see Stump 2010, Chapter 6. 
In consequence, Jerome will have as present as possible, within himself, the God who is his beloved. That is why the list of the fruits of this union begins with love, joy, and peace - love, because his beloved, who loves him, is present to him; joy, because of the dynamic interaction with his beloved, who is present to him in second-personal ways; and peace, because his heart already has what it most desires, his beloved, present to him. ${ }^{35}$

And so in the indwelling of the Holy Spirit, God is present to a person of faith with maximal second-personal presence, surpassing even the presence possible between two human persons united in mutual love. It is a union that makes the two of them one without merging one into the other or in any other way depriving the human person of his own mind and self.

\section{CONCLUSION}

So if we think about the notion of presence in all its richness, we can see that a simple consideration of God's relation to space alone is insufficient to elucidate God's omnipresence. God's omnipresence is a matter of God's relations to space all right, but to all space at all times at once, because omnipresence is an attribute of an eternal God. More importantly, because God has a mind and a will, it is possible for God to be not just present at a space but also present with and to a person. The assumption of a human nature ensures that an eternal God is never without the ability to empathize with human persons and to be present with them in the way mind-reading enables. And, in the indwelling of the Holy Spirit, God can be more powerfully present in love to a human person who loves him than any human person could be.

What it is to be omnipresent, then, is to be present in every way to everything as much as eternal divine power permits and love allows. ${ }^{36}$

${ }^{35}$ For an excellent discussion of this subject in connection with Aquinas's ethics, see Andrew Pinsent, The Second-Person Perspective in Aquinas's Ethics: Virtues and Gifts (London and New York: Routledge, 2012), especially chapter 4, in which Pinsent likens the fruition of second-person relatedness, an 'abiding in' the other, to a state of resonance.

${ }^{36}$ I am grateful to Andrew Pinsent for helpful comments on an earlier version of this paper. 


\section{BIBLIOGRAPHY}

Blakeslee, Sandra, and Vilayandur Ramachandran, Phantoms in the Brain (London: Harper Perennial, 2005)

Feinberg, Todd, John Deluca, Joseph T. Giacino, David M. Roane, and Mark Solms, 'Right-Hemisphere Pathology and the Self: Delusional Misidentification and Reduplication', in Todd Feinberg and Julian Paul Keenan, eds., The Lost Self: Pathologies of the Brain and Identity (Oxford: Oxford University Press, 2005), pp. 100-130

Gallagher, Shaun, 'Neural Simulation and Social Cognition', in Jamie Pineda, ed., Mirror Neuron Systems: The Role of Mirroring Processes in Social Cognition (New York: Springer, 2009), pp. 355-372

Gallese, Vittorio, "Being Like Me": Self-Other Identity, Mirror Neurons, and Empathy', in Susan Hurley and Nick Chater, eds., Perspectives on Imitation: From Neuroscience to Social Science (Cambridge, Mass.: MIT Press, 2005), pp. 101-118

Goldman Alvin, 'Mirroring, Mindreading, and Simulation', in Jamie Pineda, ed., Mirror Neuron Systems: The Role of Mirroring Processes in Social Cognition (New York: Springer, 2009), pp. 311-330

Goldman Alvin, 'Two Routes to Empathy: Insights from Cognitive Neuroscience', in Amy Coplan and Peter Goldie, eds., Empathy: Philosophical and Psychological Perspectives (Oxford: Oxford University Press, 2011), pp. 31-44

Hudson, Hud, 'Omnipresence', in Thomas P. Flint and Michael C. Rea, eds., The Oxford Handbook of Philosophical Theology (Oxford: Oxford University Press, 2009), pp. 199-216

Peacocke, Christopher, 'Joint Attention: Its Nature, Reflexivity, and Relation to Common Knowledge', in Naomi Eilan, Christoph Hoerl, Teresa McCormack, and Johannes Roessler, eds., Joint Attention: Communication and Other Minds (Oxford: Oxford University Press, 2005), pp. 298-324

Pinsent, Andrew, The Second-Person Perspective in Aquinas's Ethics: Virtues and Gifts (London and New York: Routledge, 2012)

Reddy, Vasudevi, How Infants Know Minds (Cambridge, Mass.: Harvard University Press, 2008)

Sacks, Oliver, A Leg to Stand On (New York: Harper and Row, 1984)

Stump, Eleonore, 'Atonement and the Cry of Dereliction from the Cross', European Journal for Philosophy of Religion, 4.1 (Spring 2012), 1-17

Stump, Eleonore, Aquinas (London and New York: Routledge, 2003)

Stump, Eleonore, 'The Nature of a Simple God', American Catholic Philosophical Quarterly, forthcoming

Stump, Eleonore, 'The Openness of God: Eternity and Free Will', in Ben Arbour, ed., (Routledge, forthcoming)

Stump, Eleonore, 'Persons: Identification and Freedom', Philosophical Topics 24 (1996), 183-214 
Stump, Eleonore, 'Simplicity and Aquinas's Quantum Metaphysics', in Gerhard Krieger, ed., Die Metaphysik des Aristoteles im Mittelalter - Rezeption und Transformation (Stuttgart: Steiner, forthcoming)

Stump, Eleonore, Wandering in Darkness: Narrative and the Problem of Suffering (Oxford: Oxford University Press, 2010)

Stump, Eleonore, and Norman Kretzmann, 'Eternity, Awareness, and Action', Faith and Philosophy, 9 (1992), 463-82 